\title{
Latest Measures to Keep Chimneys in Step with Plant Changes
}

\author{
Dr. Manoj Kr Gupta ${ }^{\mathrm{a}}$, Dr. V K Bajpai ${ }^{\mathrm{b}}$, Dr. T K Garg ${ }^{\mathrm{c}}$ \\ a: Professor in Mechanical Engineering, MMEC, MMU Mullana (Ambala), Haryana, India \\ b: Professor in Mechanical Engineering, NIT Kurukshetra, Haryana, India \\ c: Ex-Professor in Mechanical Engineering, NIT Kurukshetra, Haryana, India
}

\begin{abstract}
Chimneys and stacks are expected to operate throughout a plant life of 30 to 50 years. Pollution regulations have forced a rapid increase in chimney heights and have reached a staggering magnitude of $400 \mathrm{~m}$ plus today. These fulfil a critical function at any industrial facility and are affected by operational changes in the process cycle. To ensure long-term structural integrity, performance and life; it is required to anticipate the impact of operational changes and to develop appropriate measures. Industrieshavingsteel plant, diesel \& thermal power plants have been visited and chimney $\&$ its accessories have been studied. Guidelines have been developed to keep chimneys in step with plant changes by interacting with chimney owners, inspection contractors, consulting engineers and by own experience. The present paper is designed to provide a useful guidance tool \&set of references for practicing engineers and will result in significant cost savings.
\end{abstract}

Keywords:Stack, Liner, Draft, Velocity cone, Scrubber

\section{INTRODUCTION}

Chimney or stack is a tall structureattached to a furnace, boiler, combustion chamber or ventilation system through which waste hot gases and solid particulates are discharged at an elevation. Steel chimneys are also known as smoke stacks.While a common impression is that industrial chimneys are simple vertical tubes of steel or concrete, to be forgotten once installed, in practice these are quite complex structures. Actually, chimneys are special structures which can provide many challenges for engineers. There is, however, a virtual absence of literature which can provide inputs for a practicing engineer.In the past, customers were not aware of the necessity to covey complete specifications of the chimney to the manufacturer. The chimney manufacturers also have been reluctant to enquire more closely into customer's needs. As a result, chimneys have performed badly and not satisfied customer's expectations. Chimney failures take place due to faulty design or lack of proper inspection \& maintenance. [1,2] Moreover, IS: 6533, 'Code of Practice for Design and Construction of Steel Chimney',neither provide guidelines regarding measures to keep chimneys in step with plant changes nor a comprehensive and effective inspection and maintenance schedule.

Despite their common function, each chimney is distinct and special care has to be taken while designing a chimney.These are subjected to operating conditions that change with time e.g. fuel switching, duty cycling, structural modifications and changes due to environmental control processes. Often, owners are not familiar with the effects of environmental and operating conditions, on the behaviour of these structures and do not recognize early signs of distress. The impact of changes must be recognized and maintenance procedures are to be developed and upgraded. Effectiveinspection and maintenance schedules are to be developed\& upgradedin step with plant changes for individual chimney. Chimneys are exposed to a variety of changesduring their lifespans. The impact of following changes on chimneys has been explored and corrective measures have been suggested:

\section{$>$ Production Level Changes \\ $>$ New Boiler Additions \\ $>$ Extending Chimney Height \\ $>$ Environmental Protection Measures}

\section{Production Level Changes}

A drop in plant production leads to less fuel use, lower flue gases volume and reduced flue gases exit velocity. A very low exit velocity leads to quick cooling, wash-down and scattering of particulate in the vicinity of the chimney. Low velocity also contributes to particulate buildup on the liner and as a result, more frequent cleaning of the liner is required.A velocity cone is used to combat the effects of low flue gases volume. A cone increases flue gases exit velocity and is installed at the top of chimney. The increase raises the effective height of the stack and improves particulate dispersion.Velocity cones must be properly designed for the system's capacity. If induced draft fan is part of the system, the cone must be compatible with fan capacity. A velocity cone creates pressure drop. Draft calculations are required to verify the adequate draft in the chimney after all the losses. The structure must be evaluated to ensure that it can withstand the additional wind pressure created by the cone.

At one of the steel plant, it was found that the top portion of the stack of 'Electric Arc Furnace' was badly corroded after few years of operation. The plant wasshut down for five days to fit a new stainless steel velocity cone at the top of the stack. 


\section{New Boiler Additions}

If growing energy requirements demand addition of more boilers to existing smoke-stacks, new openings are needed in the outer shell and liner of the stack. The openings, coupled with changes in flue gases volume and temperature, change critical stresses and draft conditions.Openings should be cut by evaluating the stress conditions created by the proposed modifications for both the chimney and the liner. A new opening that is smaller than the existing ones andinstalled at the same elevation at $180^{\circ}$ from existing openings does not cause excessive stress. Even under these conditions, the edges of the new opening should be properly stiffened or a reinforced sheath be installed to mitigate the stresses [3, 4].

Increased flue gases volume and possible temperature changes may exceed the chimney's capacity and significantly change the draft. If the flue gases volume is too high, an induced draft fan isrequired.For a chimney that undergoes changes in flue gases characteristics and draft conditions, a more frequent inspection program should be considered to evaluate the impact of these changes on construction materials [5].

Addition of new flues to existing steel liners poses other potential problems. In most cases, a temperature differential occurs inside the liner and promotes liner plate buckling. Evaluations are to be focused on linerplate stresses caused by non-uniform gas temperatures. A temperature differential of more than $25^{\circ} \mathrm{C}$ makes a study of possible liner reinforcement vital. Horizontal and vertical stiffeners are to be installed and the existing number of bumpers and stay rodsare to be modified. Chimney liner moves vertically and laterally. Stayrods and bumpers restrain the free thermal movement of the liner and induce thermal stresses. Removing stayrods near the bottom of the liner may reduce liner plate stresses and eliminate the need to anchor the stayrods onto the concrete column.

\section{Extending Chimney Height}

Criteria for acceptable safe concentrations of pollutants are undertaken by a number of organizations including the 'World Health Organization', national expert committees and governments. In European Union, member countries are moving towards a common set of air qualities limit values. In United States, National Ambient Air Quality Standards have been set under the 'Clean Air Act'. In India, 'National Ambient Air Quality Standards' are set by 'Central Pollution Control Board' (CPCB) and are recently revised in Nov, 2009. The limit values of pollutant concentrations are shown in Table 1. Chimney height is determined primarily by ground level concentration limits on contaminants as $\mathrm{SO}_{2}, \mathrm{NO}_{2}$ and particulates as stipulated by $\mathrm{CPCB}$ [2]. A significant change in a plant's operating conditions may require a chimney height extension to allow dispersal of flue gases at a higher elevation to satisfy CPCB requirements.Latest concrete chimneys and steel stacks do not have excessive structural strength safety margins.Height extension affects the stress conditions by increasing the moments caused by wind loads.In addition, the revised height must not produce excessive friction losses or change the original draft conditions of the chimney [6].Special attention should be paid to the top of the chimney. It often deteriorates and may require surface preparation or partial removal before any extension is done.

\section{Environmental Protection Measures}

Emission control equipments are required to comply with the 'National Ambient Air Quality Standards'. Methods to reduce $\mathrm{SO}_{2}$ levels are installing wet scrubbers or switching from high sulphur to lowsulphurfuel. Both methods have an impact on chimney performance and longevity.

The use of present day high efficiency boilers has led to lower fluegases temperature which has sharply increased the chances of acid formations and corrosion of an unlined steel chimney. However, a lower temperature may be tolerated since a small gain in thermal efficiency can save considerable annual revenue, justifying the use of more expensive chemical resistant liner.Reinforced concrete cement (RCC), brick, steel and fibre-glass reinforced plastic (FRP) are the common materials for chimneys, stacks and liners. At present steel liners are popular in RCC chimneys because they are impervious to gases and compared to bricks, are lighter and permit a high gas velocity. Carbon steels liners are used up to temperature of $400^{\circ} \mathrm{C}$. Steel with chrome and nickel can be used up to $600^{\circ} \mathrm{C}$ and special steel with silicon is resistant up to $900^{\circ} \mathrm{C}$ $[7,8]$. 
Table 1 National Ambient Air Quality Standards [CPCB, Nov 2009]

\begin{tabular}{|c|c|c|c|}
\hline \multirow[t]{2}{*}{ Pollutants } & \multirow{2}{*}{$\begin{array}{l}\text { Time } \\
\text { weighted } \\
\text { average }\end{array}$} & \multicolumn{2}{|c|}{ Concentration in ambient air } \\
\hline & & $\begin{array}{l}\text { Industrial, Residential, } \\
\text { Rural \& other Areas }\end{array}$ & $\begin{array}{c}\text { Ecologically Sensitive Areas } \\
\text { (notified by Central } \\
\text { Government) }\end{array}$ \\
\hline \multirow{2}{*}{ Sulphur Dioxide $\left(\mathrm{SO}_{2}\right)$} & Annual & $50 \mu \mathrm{g} / \mathrm{m}^{3}$ & $20 \mu \mathrm{g} / \mathrm{m}^{3}$ \\
\hline & 24 Hours & $80 \mu \mathrm{g} / \mathrm{m}^{3}$ & $80 \mu \mathrm{g} / \mathrm{m}^{3}$ \\
\hline \multirow{2}{*}{$\begin{array}{l}\text { Nitrogen } \\
\text { Dioxide } \\
\left(\mathrm{NO}_{2}\right)\end{array}$} & Annual & $40 \mu \mathrm{g} / \mathrm{m}^{3}$ & $30 \mu \mathrm{g} / \mathrm{m}^{3}$ \\
\hline & 24 Hours & $80 \mu \mathrm{g} / \mathrm{m}^{3}$ & $80 \mu \mathrm{g} / \mathrm{m}^{3}$ \\
\hline \multirow{2}{*}{$\begin{array}{c}\text { Particulate } \\
\text { Matter (size less than } 10 \mu \mathrm{m} \text { ) or } \\
\mathrm{PM}_{10}\end{array}$} & Annual & $60 \mu \mathrm{g} / \mathrm{m}^{3}$ & $60 \mu \mathrm{g} / \mathrm{m}^{3}$ \\
\hline & 24 Hours & $100 \mu \mathrm{g} / \mathrm{m}^{3}$ & $100 \mu \mathrm{g} / \mathrm{m}^{3}$ \\
\hline \multirow{2}{*}{$\begin{array}{c}\text { Particulate } \\
\text { Matter (size less } \\
\text { than } 2.5 \mu \mathrm{m} \text { ) or } \mathrm{PM}_{2.5}\end{array}$} & Annual & $40 \mu \mathrm{g} / \mathrm{m}^{3}$ & $40 \mu \mathrm{g} / \mathrm{m}^{3}$ \\
\hline & 24 Hours & $60 \mu \mathrm{g} / \mathrm{m}^{3}$ & $60 \mu \mathrm{g} / \mathrm{m}^{3}$ \\
\hline \multirow[t]{2}{*}{ Ozone $\left(\mathrm{O}_{3}\right)$} & 8 hours & $100 \mu \mathrm{g} / \mathrm{m}^{3}$ & $100 \mu \mathrm{g} / \mathrm{m}^{3}$ \\
\hline & 1 hour & $180 \mu \mathrm{g} / \mathrm{m}^{3}$ & $180 \mu \mathrm{g} / \mathrm{m}^{3}$ \\
\hline \multirow[t]{2}{*}{ Lead $(\mathrm{Pb})$} & Annual & $0.50 \mu \mathrm{g} / \mathrm{m}^{3}$ & $0.50 \mu \mathrm{g} / \mathrm{m}^{3}$ \\
\hline & 24 Hours & $1.0 \mu \mathrm{g} / \mathrm{m}^{3}$ & $1.0 \mu \mathrm{g} / \mathrm{m}^{3}$ \\
\hline \multirow[t]{2}{*}{ Carbon Monooxide (CO) } & 8 hours & $02 \mathrm{~g} / \mathrm{m}^{3}$ & $02 \mathrm{~g} / \mathrm{m}^{3}$ \\
\hline & 1 hour & $04 \mathrm{n}$ & $04 \mathrm{mg} / \mathrm{m}^{3}$ \\
\hline \multirow[t]{2}{*}{ Ammonia $\left(\mathrm{NH}_{3}\right)$} & Annual & $100 \mu \mathrm{g} / \mathrm{m}^{3}$ & $100 \mu \mathrm{g} / \mathrm{m}^{3}$ \\
\hline & 24 hours & $400 \mu \mathrm{g} / \mathrm{m}^{3}$ & $400 \mu \mathrm{g} / \mathrm{m}^{3}$ \\
\hline Benzene $\left(\mathrm{C}_{6} \mathrm{H}_{6}\right)$ & Annual & $05 \mu \mathrm{g} / \mathrm{m}^{3}$ & $05 \mu \mathrm{g} / \mathrm{m}^{3}$ \\
\hline $\begin{array}{l}\text { Benzo (a) Pyrene (BaP) - } \\
\text { Particulate phase only }\end{array}$ & Annual & $01 \mathrm{ng} / \mathrm{m}^{3}$ & $01 \mathrm{ng} / \mathrm{m}^{3}$ \\
\hline Arsenic (As) & Annual & $06 \mathrm{ng} / \mathrm{m}^{3}$ & $06 \mathrm{ng} / \mathrm{m}^{3}$ \\
\hline Nickel (Ni) & Annual & $20 \mathrm{ng} / \mathrm{m}^{3}$ & $20 \mathrm{ng} / \mathrm{m}^{3}$ \\
\hline
\end{tabular}

Integrating a wet scrubber into an industrial process changes the characteristics of the flue gases, increasingmoisture content and lowering the temperature. Lower temperatures cause a loss of static draft andcombined with higher moisture content, the condition stimulates condensation and leads to acid attack on the interior of the liner.Positive pressure tends to cause the flue gases to penetrate the brick liners and damage the metal components in the air space. The modification is accomplished by increasing the air pressure in the annulus to a level higher than the flue gases pressure inside the liner, thereby minimizing flue gases penetration $[9,10]$.

When operating conditions are below the dewpoint, the increased potential for corrosion exists in the ductwork, lining and accessories. These areas should be inspected more frequentlyto determine how effectively the materials are resisting chemical attack. Flue gases, with abrasive and corrosive characteristics, can damage the structural materials of chimney or liner.Liners particularly vulnerable to corrosive flue gasesshould be protected with an acidresistant coating, Guniteor steel cladding. In some cases, it 
is costeffective to replace the liner with one suitable to the new operating conditions.

Increased flue gases volume and velocity scour the liner surface, allowing flakes of deposited material to escape and thorough cleaning of the liner's inside surface is required. Higher moisture levels also requireadequate cleaning at the base of the chimney or stack $[11,12]$. It has been found that ash handling is a major problem in Thermal Power Plants.

\section{CONCLUSIONS}

Chimneys are key elements in the processes to which they are linked. The consequences of chimney damage or deterioration are quite disastrous in economic terms. The practices suggested in the present paper are comprehensive and well designed and may be used as a basis for implementation. The impact of changes in plant production, energy requirements and environmental regulations must be recognized and corrective measures are to be taken as per guidelines suggested. Maintenance procedures are to be developed and upgradedin step with plant changes.Maintenance procedures must be designed for individual chimney $[13,14]$.It is hoped that the present paper will lead to a better pragmatic approach for practicing engineers and will lead to significant cost savings.

\section{REFERENCES}

1. KaemmerKlaus K. et.al, The CICIND Chimney Book, ComiteInternational Des ChemineesIndustrielles, (CICIND), 2005, 309-321.

2. Hertlein Bernhardt H., Chimney and Stack Inspection Guidelines, American Society of Civil Engineers, 2003, 1-13, 55-58.

3. SimonovicAleksandar M., Stupar Slobodan N.,PekovicOgnjen M., Stress Distribution as a Cause of Industrial Steel Chimney Root Section Failure, FME Transactions, 36, 2008, 119-125.

4. Chimney Maintenance Guide, Comite International Des ChemineesIndustrielles (CICIND), 2006.

5. Guide to the Inspection of Single Flue Industrial Steel Chimneys, ATLAS (Association of Technical Lightning \& Access Specialists), Feb2004.

6. "Corrosion Protection for Chimneys in Flue Gas Systems", 3 L\&T Inc., USA, www.3L-T.com.

7. BhowmickArun K.,Maintenance Spells Extended Life for Chimneys and Stacks,HamonCustodis; http://www.hamonusa.com.

8. "Industrial Chimney Stacks", Stone Technical Services Ltd., UK, www.stoneservicesuk.com.

9. "Specification for Inspection of Steel Chimneys", Consortium Local Authorities, Wales, Maintenance Module 12(1), Feb 2007.

10. Mix Paul E., Introduction to Non- destructive Testing a Training Guide, John Wiley \& Sons, New York, 2005, 457 519.

11. Dr. Gupta M. K., Dr. Bajpai V. K., Dr. Garg T. K., Computation of Design Parameters of Smoke Stacks, Ph. D. Thesis, NIT Kurukshetra (India),2013.

12. IS: 6533-1989 (Part II), Code of Practice for Design and Construction of Steel Chimney, Structural Aspect, Bureau of Indian Standards, 14-15, Reaffirmed 2003.

13. Dr. Gupta M. K., Dr. Bajpai V. K., Dr. Garg T. K., Long-Term Structural Integrity of Steel Stacks: Proposed Tools for Inspection \& Maintenance, International Journal of Mechanical Engineering, 3(1), 2010, 131-133.

14. www.cbcb.nic.in 